\title{
A Situational Analysis Of Issues And Challenges Faced By Social Work Students During Their Field Placements In Karachi, Pakistan
}

\author{
Sakina Riaz \\ Department of Social Work \\ University of Karachi
}

\begin{abstract}
Field work is viewed as the important pillar of Social Work profession. The aim of this study is to examine the issues and challenges faced by the Social Work Students during their Field Placement in different agency settings. This study articulates the teaching philosophy, conceptual framework, and fieldwork practices followed by Student of Social Work Department at Karachi University. Qualitative research design was employed in this study and purposive sampling strategy was used for data collection. The results of the study drawn that the main constraints stem from a lack of social work agency supervisors, lack of training for agency supervisors, the lack of a fieldwork curriculum and nonexistent or insufficient funding of fieldwork related activities.
\end{abstract}

Keywords: Student's of Social Work, Issues, Challenges, Field Placements.

$$
\begin{aligned}
& \text { تلخيص }
\end{aligned}
$$

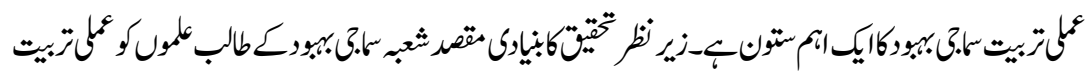

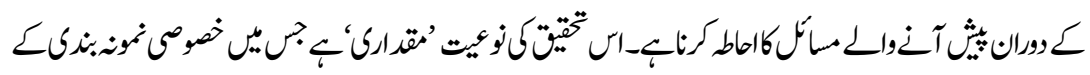

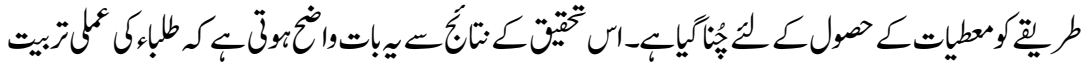

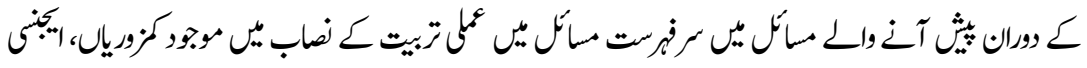

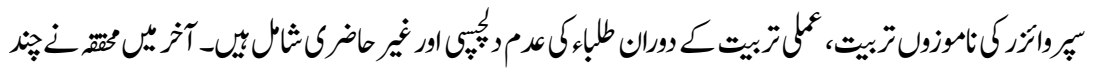

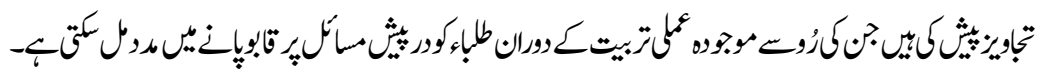

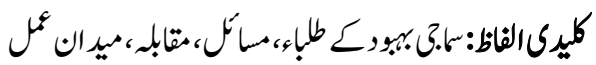

\section{Introduction}

Martin Luther King, Jr.Minister, Civil Rights Activist told that :

"Never, never, be afraid to do what's right, especially if the well-being of a person or animal is at stake. Societies punishments are small compared to the wounds we inflict on our soul when we look the other way" (Esiasa, 2014). 
Social Work is an international profession which has constantly incorporated with an academic and practical component. Social Work as profession is flourishing in every corner of the world. As Social Work extends its influence across the region, it includes an increasing variety of theories and practices. Social Work education comprises of a theoretical module that educated in the classroom and Field- based training; involving combination of the academic aspect and practice. In a policy declaration NASW indicated that:

"Employing organizations should encourage and support social workers' participation in professional development activities. This can be accomplished through organizational sponsorship of multidisciplinary and social work-specific continuing education programming; promotion of supervision and mentorship opportunities for social workers; and support for social work involvement in peer review, research, publication, and volunteer activities" (NASW, 2016:9).

Field Work offers an opportunity to Social Work Students to apply their Social Work skills and knowledge in to practice while handling with multi-dimensional problems of contemporary society. Nevertheless, Field education and supervision remains at the center of any Social Work Practice and has cornerstone for professional development of young social worker. Field exposure promotes student's ability to learn quickly at grass root level. Field Placement provides learning opportunities in a real life situation and observed as "the missing link between theory and professional practice" (Parker, 2007). Indeed, it is a method of practice for applying social work theories and knowledge into practice. Yet, Field Work Practice in Social Work is considered as learning through doing, it provides a chance to students to apply their theoretical knowledge taught in the classroom appropriately in real-life situations.

The history of Social Work education discloses that, since the establishment of the first schools of social work till now, Field Placement learning has been at the heart of social work education (Papouli, E.2014). The structure of Field Work Practicum is constructed on three important pillars that are Field Advisor, Field Supervisor and the Student. The Field Advisor acts as an arbitrator between the Student and the Field Supervisor and performs an important job of building the bridge between University curriculum and Field orientation. Often it is the responsibility of the Field Advisor to supports as a liaison person between the Students and the Field supervisor; communicates with agency and Supervisor about educational issues and makes all possible efforts to implement the University educational calendar. Furthermore, it is also the responsibility of Field Advisor to keep the student performance and their attendance at Field site. In this regards, Field advisor used to pay surprise visits to the concern agency where these students has been deputed for two consecutive semesters. 
The Field Supervisors generally are the agency representative Social Workers, most of them long standing professionals. They helps student in understanding the important functions of the agency and the roles of the staff involved in their training and professional development.

All the activities of the Students revolve around objective of the agency; where they are placed in the field for formal training of Social Work. In Pakistan, Field Work Placement for Student starts at their first year of Master level education at University. In order to obtain the degree, students do fieldwork .They have to spent their two semester, twice a week at Field Agency during both the first and second years of study.

\section{Literature Review}

University education as the highest academic institution in any country with the main role of training its youth for pursue better career in their professional life (Mngomezulu, 2013). states that higher education should "kindle national interests in the youth, uplift its citizens and free them from ignorance, superstition and lethargy". It is generally understood that practice learning is necessary to enable students to integrate theory and practice and to contextualize learning (Buam, 2011).

Fieldwork is the important component of Social Work education which provides ample opportunities of learning. Bogo et al. (2010:163) pointed out that "students learn to practice social work through delivering social work services in agency and community settings". No doubt, it is the forum in which the beginner Social work profession and develops core skills and competence and a critical and reflective approach (Parker, 2007). The supervisor, or practice teacher, is played a pivotal role to these pursuits (Doel and Shardlow, 2005). Prof .R.R Sing mentioned that Field Work practice is assumed to occur by "applying theory". Field placements are at the heart of Social Work training (Lomax \&Jones, 2014). Field Work is the training process for the students, through which they learn to develop and execute intervention strategies for bringing about a positive change in the society.

Agreeing with Garthwait (2014) who states that, "the Fieldwork Practicum is an experience that requires the practical application of theory or conceptual knowledge". Hence, Field Work Practice as a core course in Social Work education that requires all students to undertake Field education as part of their professional training. 
Dhemba (2012) verify that Fieldwork practice enhances the practical component of Social Work training thus guides students to apply knowledge and general principles to real life situations, problems, and concerns.

Evans and McDermott (1988) expressed this concisely when they referred to placing a Student in Fieldwork as 'not simply an administrative task, but the outcome of a coalescing or mutuality of interests of players in a covertly disruptive domain'. The apprenticeship perspective provides comprehensive guidance to educational practices such as supervision of students in their field exposure. However, there is some evidence that students often enter their Placements with apprehension, stress, anxiety, and unclear expectations, negative emotions that may well interfere with effective learning (Barlow \& Hall, 2004; Barlow et al, 2006; Gelman, 2004; Rompf, Royse, \& Dhooper, 1993).

With regard to the process, significant scholarly attention has been given to the processes, problems, and issues in fieldwork and supervision (Munson,1993; Shulman, 1993; Kadushin and Harkness, 2002).Students problems or conflicts associated with the supervisor transaction were related to greater student distress in their fieldwork and this issues were discussed by many scholars (Barlow \& Hall, 2003; Barlow et al., 2006; Giddings et al., 2003; Tepper, 2000).The review of literature has evidently revealed that students are usually motivated and ready to learn are in a safe, respectful environment and contribute in the process of learning (e.g. Shardlow \& Doel, 1996; Bogo, 2010; Doel, Shardlow, \& Johnson, 2011).

In Pakistan, Fieldwork Placement is a requirement for the students of Master of Social Work at the department of Social Work in University level of education. Although; Master in Social Work is a two year education programme in the universities at Karachi and Fieldwork is a generic course (HEC, 2015).Field Placement procedure is quite different in Universities (i.e. the University of Karachi and Federal Urdu University) and here field placement in restrict to two days in week in an agency setting. We do not follow book field placement procedure. The curriculum of M.A in Social Work at University of Karachi has been divided into four semesters, with two semesters in each academic year. It can be said that four days in a week affixed for the classroom teaching and fieldwork is scheduled on two days of the week.

In the department of Social Work, University of Karachi, the Field Placement process starts in the beginning of the academic calendar or semester at Maters level. Apart from class room teaching, students have been assigned their respective field, called "agency" for twice a week in two regular's semesters until completion of Master. This placement is consisting of two parallel semester's. In each year Field placement is rotated. Student of M.A first year supposed to be deputed in community development fields. Whereas, students of MA final has 
been placed in Medical setting. Students training done by Field Advisor but students' performance evaluation has to be evaluated by both Advisor and Supervisor during semester examinations. Prior to the placement, the field advisors provide the necessary field guidance to the students. Usually, a gender mixed group of student is assigned for Field Placement. This placement is carried out in a large variety of public sector agencies (e.g. welfare departments, hospitals, mental health clinics, etc.), with students rotation to a different agencyand different supervisor-every year.

\section{Significance of the Study}

In Pakistan, there is very less scholarly work has been done on the need and importance of Field Work. This paper highlight "Field Work Practices in Social Work Education" as a vital means to enhancing a developmental perspective to the profession, discussing its scope and strategies in the Pakistani context and specially with reference to Karachi.

The focus of the study is to see what factors support to the students in providing the Field training and how the Students can continue to improve the level of understanding and be able to grasp the Field dynamics easily.

\section{Study Objectives}

- To understand the field work practicum is designed and implemented in the department of social work in University of Karachi;

- To explore the experiences, problems and challenges faced by the Student of Social Work Department at their field placement;

- To identify the attitudes of students towards field practices.

- To find out the opinion of stakeholders in evaluating the existing field challenges.

\section{Research Question}

Taking into the consideration of the challenges for Field Work professional, Social Work Educators and the Students, the author aim to address the following questions;

1. What are the students' perceptions about their field work training?

2. How field supervisor view's their role in providing the training to the students and what are their main issues?

3. What are the social work faculty's perceptions about performing their duties as field advisor and how they manage it?

4. What are the administrative issues which need to be resolved in order to improve the existing field practices mechanism? 


\section{Research Methodology}

The main purpose of this paper is to identify challenges of Field education which are being faced by the Students of Social Work Department in Karachi city. This study is also anticipated to provide in-depth evaluation of existing condition and situations. The researcher had used the Qualitative research method. The target population of study is field supervisors, field advisors and students majoring in social work. Using a purposive technique of non-probability sampling methodology, in-depth interview were conducted from faculty, Field supervisors and final year students of the Department of Social Work in University of Karachi. Purposeful sampling technique includes identifying and selecting individuals or groups of individuals that are especially knowledgeable about or experienced with a phenomenon of interest (Creswell and Plano Clark 2011).

To better understand the issues and challenges faced by the students; the researcher has chosen three different study groups as sample for this study and conducted face to face interviews from these groups (i.e. Group ' $A$ ' Group 'B' and ' $C$ ' ). Details of respondents categorized for each study groups are mentioned here under:

1. Group 'A' consist of faculty members who are also served as Field Advisor for selective group of students of the department of social work.

2. Group 'B' consist of Field Supervisor who worked in different NGOS, GOs and also worked as Field supervisor for the selective group of students nominated by the department of social work.

3. Group ' $\mathrm{C}$ ' represents the student of social work (M.A final year, which have the field exposure of almost one year in community and hospital setting).

The distribution of respondent is given in Table 1

Table: 1

Allocation of sample stratum

\begin{tabular}{|l|l|c|}
\hline \multicolumn{1}{|c|}{ Categories of Respondents } & $\begin{array}{c}\text { Respondents } \\
\text { Background }\end{array}$ & $\begin{array}{c}\text { No. of } \\
\text { Respondent }\end{array}$ \\
\hline $\begin{array}{l}\text { 1. Academia from Social Work department } \\
\text { University of Karachi }\end{array}$ & (Group A) * & 04 \\
\hline $\begin{array}{l}\text { 2. Professional from different NGOs who } \\
\text { are working with the department of Social } \\
\text { Work as field supervisor. }\end{array}$ & 07 \\
\hline $\begin{array}{l}\text { 3. Students From Social work department } \\
\text { University of Karachi }\end{array}$ & (Group C)*** & 09 \\
\hline Total Respondents & \multicolumn{2}{|c|}{$\mathbf{2 0}$} \\
\hline
\end{tabular}

- Full time faculty members.

- ** Professional who also worked as Field Supervisors in Karachi.

- $\quad * * *$ Student of MA final year, Department of Social Work, university of Karachi. 
Considering the nature of present study, the researcher adopted interview schedule technique and designed an interview scheduled guide to obtain the data from representatives of each group. A pretest was administered to determine the reliability and validity of the instrument. The reason for conducting face to face interview was to gather as much information as possible and to identify any other related additional factors which have not been explored in the literature review. As in- depth interview relies on individuals in the research process and considers individuals as important and knowledgeable resources about the social world which can be shared via verbal communication (Hesse-Biber \& leavy, 2006).

The inclusion criteria for the participants selected for present study was professional who had at least two years of experiences as a Social Work Field Advisor or Field Supervisor. For taking the representation from Students, selection criterion was decided that student may have their one year work experience in Field. The reason for having this criterion was that the respondents have an experience and quite aware of the depth and gravity of the issues and may evaluates better.

\section{Results \& Discussions}

The aim of this research was to investigate the various dynamics involved at field practicum. Therefore, the analysis has been guided by the question of what are the issues and challenges faced by Social Work Students during their Field Placements in Karachi city. Therefore, the interview scheduled guide was specifically covered the following key themes for discussion and mentioned as follow:

1. Students' perceptions about their Field Work training;

2. Field Supervisor view's regarding their role in providing the field training;

3. Faculty Challenges in performing their duties as Field Advisor;

4. Field Agency Related Administrative Issues.

The details of the analyses and discussion are narrated as under:

\section{Students' Perceptions about Their Field Work Training}

Social work as a practiced-based profession (IFSW/IASSW, 2014) which requires a lot of consecration .In the present study it was revealed that majority of the Students were viewed that Field Placement is not easy to continue with theory classes as they have the pressure of learning at the Field and have to complete Field assignments within allotted time.

Almost all Students showed their great dissatisfaction regarding shortage of Field Supervisor with Social Work Educational background. Placements in settings where non-professional Social Worker are working as a Professional, often creates 
lots of problems for students learning. As a matter of fact in hospital settings or in community development setting it is observed that people who have not professional Social Work degree but they are appointed as Social case worker or community development officer. This is a serious matter and it is caused great difficulties in understanding of the perception of case work, process record management and daily diary maintenance as many non-professionals usually ignore its due importance. Students were the opinion that Government should appoint a professional Social case worker or social welfare officer in all hospitals which will be able to help better in handling patients' psycho-social problems.

In response to a question regarding the Gender of Field Supervisor and their work habits, it was revealed that the most of Field Supervisor were female (82\%) in the present study affirmed by earlier studies. (NSWQB, 2006), as well as the perception that social work is 'mainly a woman's profession' (Bruckner, 2002: 269; Christie, 2008) and regarding the work style or work habits, it was highlighted by the students that male Field Supervisor $(77 \%)$ are having good knowledge, and better communication skills with students whereas majority of female Field Supervisor having strict behavior with students (53\%) at their Fields respectively. Furthermore, it was also pointed out by the respondents that female Supervisor's attitude towards welfare assignment is very responsive. This finding is quite similar to an earlier study which showed that "women have been found to be more welfare -oriented" (Konard et al., 2000). Referred to the question about Field learning environment, it was noticed through student's group discussion that students are facing problems in seating arrangements at their Fields. Shortage of space or congested office is a major problem (72\%) reported by students which creates disturbance in their learning. Students expressed that usually male students used to stand for long hours in front of their Field Supervisor due to nonavailability or shortage of chairs for them.

\section{Field Supervisor View's their Role in Providing the Training}

Almost all Field Supervisors were pointed out that Students Field Placement usually creates additional stress and burden for them as well as for the respective agency too. Majority was the opinion that students are not serious towards their studies and usually delays their Field Work assignments. Refer to the question of student regularity at Field, it was highlighted by the respondents that students are not regular and punctual at their Field .Student late arrival at Field (i.e. around 10:30 a.m.) and early departure from the Field (i.e. 1:00) is the common practice, stated by the majority of the Supervisor (96\%). It was put forwarded by majority of the Supervisors $(87 \%)$ that majority of the students take leaves without any prior information to their concerned Field Advisors or Supervisors and often they submitted lame or baseless excuses as reason. On the basis of these stated facts, it can be said that student attitude towards their Field Work is non-serious and 
absenteeism from Field is revealed as a major finding from the present study and this result is quite similar with the earlier research as in a research of Gelman, 2004, one major finding was "the main factors possibly responsible for negative fieldwork experiences is the students' level of preparation when they enter the field".

Interestingly, students attitude about Field assignments, presentations and community visits or any other activity as assigned by the Field Supervisor, it was mentioned by the respondent that Student took great interest and they are highly motivated towards these activities. On this basis it can be concluded that students are greatly motivated towards Field Practice assignments. The researcher has perceived that majority of the supervisors do not update their theoretical knowledge base which often creates confusions for students. Nevertheless the IASSW and IFSW (to which they are members) demand the need for training institutions to capacitate agency supervisors (Dhemba, J.2012). However, here in Pakistan the situation at Field placement is very different as indicated in the present study and need immediate steps for its development.

\section{Faculty Challenges in Performing their Duties as Field Advisor}

The job of field work supervisor is very important and crucial if field supervisor are not providing the proper orientation just because they are not getting enough salary or extra pay from university or their respective organization for the training which they offer to the student of social work. It is importantly to note that the universities at Sindh level are following HEC Field Practicum in the Curriculum of Social Work and working accordingly. Although the curriculum structure and the number of courses offered notable but unfortunately there is barely a standard of document on field work practicum which links theory to practice in Pakistani social paradigm. This vacuum creates confusions not only for students, agency supervisor but also creates extra pressure on field advisors to continuously work to meet the field work objectives.

Lots of administrative problems were highlighted by the Field Advisor in their interview; the author summarized them as under;

- Shortage of faculty;

- No fixed Teacher and Student ratio for Field placement \& guidance.

- Work load of regular class room teaching;

- Handling of field students concerns and placement issues in consultation with HOD of the department and Field Supervisors;

- Non-availability of departmental transport facility for Field Visits;

- Work load for Field Programme Monitoring. 
As per practice, each faculty has to oversee the issues of two agencies one from community development setting and one from medical setting. Four days involve in Field (Different field days for MA final Monday \&Tuesday are the field days and Wednesday \& Thursday are fixed for MA previous year)

\section{Field Agency Related Administrative Issues}

Although, a number of private NGO are offering their services as "agency" to the universities on voluntarily basis for student placement .As a matter of fact this practice helps the NGO sector not only in building their image and also provide the human resources without any financial burden. On the other hand, students are able to learn about latest skills through real life exposure.

Similarly, one major problem were arises from students side is the selection of agency as choice or specialty at field placement. In fact, that there is no any provision of getting admission of their preference at field placement. They have been appointed by the departmental heads, faculty and in consultation with the chief of the agency and there is no any option for student to opted the agency of choice or specialty .In many cases, the departmental head and concern faculty used to assign the students field placement agency near to their residence or any convenient place. This is a big favour from departmental side which generally keeps away the from many hassles especially long distance traveling at their own cost but students learning of choices or specialty concerns are usually compromised.

A number of issues were highlighted and discussed by the faculty member and students such as the purpose of the field training, divergence in curriculum content and agency vision, mode of field work the student's performance. It was revealed that in most of the agencies institutions has no concurrent Field Work Module for student's training. Students showed great level of dissatisfaction. Indeed, there should be a proper Fieldwork training mechanism with structured activities. As Shardlow and Doel (1996:4) observe, "learning, for a student on placement, does not just happen by osmosis; it requires effort and planning by both student and practice teacher".

In addition, the respondents who participated in the group discussion for this study were able to reflect on their experiences working in the different communities. In this regards, severe negative attitudes were discussed by the female participants regarding the bad experience received from family member or relatives .It was felt that students who belongs to low -socio income background are often unable to convince to their family to grant permission for field visits specially in community settings. It was revealed that most of parents of the respondents were unaware about Field Placement as a generic course in Social 
Work and they were reluctant to allow their daughters for different community visits or work. This situation could be handled if the concern department may conduct Student / Guardian interview before admission in the department and briefly inform them regarding the nature of Work or curriculum.

The study provided only very modest support for the expectation that preparation for the field experience would facilitate higher student satisfaction with the field experience, and this contribution was apparent only indirectly when operating through its influence on perceived efficacy or competence. This result, though lessened, was consistent with some previous research (Alperin, 1998; McPherson \& Barnett, 2006).

\section{Recommendations}

Throughout the world it is a matter of fact that Field Work training is always has a challenge and opportunity for both the students and supervisors as well. It is the time for academia, and policy makers to engage all stakeholders in policy discussion concerning with education and social service delivery systems in Pakistan and make a uniform policy for field training.

This study strongly recommended that:

- There is a dire need for close collaboration between Government and University academicians.

- It is suggested that a structural Field Placement manual may be designed for student's convenience.

- The Government of Sindh may provide a market based additional allowance to all social welfare officers who are working as Field Supervisor. Government of Sindh may involve this raw and human resource (students of social work department) and may utilize their capabilities and can improve their work with students' fresh perspectives.

- This research is also suggested that the appointment of a Field Supervisors, it is necessary that the person must have a minimum of five years of social work experience in the Field and have the degree of Master in Social Work.

- It is strongly recommended that Professional Social Workers should be employed in NGOs . In this regards, government should play their vital role.

- This research is suggested that a six month student paid internship program may also be introduced in the Social Work curriculum and opportunities may be provided to the students to work \& learn in different governmental agencies like the social welfare departments, disaster management department, population welfare department This will enables the students to understand the organizational working set-up in a 
booked or fix time duration. an after this internship they have to go through an assessment.

- There should be a prescribed a faculty- student's ratio for the student placement in different agencies so the quality of learning may not compromised.

- This research strongly recommended that student admission procedure for Social Work needs to be revised. It is suggested that student's aptitude test and parent's interview this will be taken before the final admission.

\section{Conclusions}

It is concluded that Social Work Field Practice in Pakistan has not exposed any considerable change and to a great extent. Social Workers, with few expectations, continue to be occupied with services delivery roles. It is all the more distressing that even in these roles, they have failed to achieve the professional expertise which was expected them and as a result, many other disciplines and professions have been progressively displacing them from areas which were considered specific areas of social work field practice .It is the time to fill the gap between theory and Field practices. It is the time to play a much wider role than merely confining to be a dispenser of social welfare services otherwise the curriculum of Social Work and the entire training programme of Field Work Placement have so far remained unaffected or limited by the time.

\section{Reference}

Alperin, D. E. (1998). Factors Related to Student Satisfaction with Child Welfare Field Placements. Journal of Social Work Education, vol.34, pp.43-54.

Barlow, C, \& Hall, B. (2004). Issues of Power and Resistance in Social Work Education, International Journal of Learning, vo.10, pp.2663-2670.

Barlow, C, Phelan, A., Hurlock, D., Sawa, R.,Rogers, G., \& Myrick, F. (2006). Virginia: A Story of Confiict in Social Work Field Education. Affilia: Journal of Women and Social Work, vol.21, pp.380-390.

Baum Nehami, (2011). Social Work Students' Feelings and Concerns about the Ending of their Fieldwork Supervision. Social Work Education, vol.30:1, pp.83-97.

Bogo, M., Litvack, A. \& Mishna, (2010). Emotional Reaction of Students in Field Education: An Exploratory Study. Journal of Social Work Education, vol.46:2, pp.227-243. 
Bruckner, M. (2002). On Social Work and What Gender has Got to Do with It, European Journal of Social Work, vol.5:3, pp.269-276.

Christie, A. (2008). The Gender Profile of the Social Work Profession in Ireland. Where are the Men? Irish Social Worker, Summer 2008, pp.21-24.

Creswell, J. W. \& Plano Clark, V. L. (2011). Designing and Conducting Mixed Method Research (2nd ed.). Thousand Oaks, CA: Sage.

Doel, M. \& Shardlow, S. (2005). Modern Social Work Practice: Teaching and Learning in Practice Settings, Arena, Aldershot.

Dhemba, Jotham (2012). Fieldwork in Social Work Education and Training: Issues and Challenges in the case of Eastern and Southern Africa, Social Work and Society International Online Journal, vol.10:1, retrieved from: http://www.socwork.net/sws/article/view/310/651

Evans, S. \& McDermott, F. (1988). Who is to Control the Practice of Social Work?' Australian Social Work, vol.41:4, pp.4-8.

Esiasa, K. (2014). Highway to My Destiny (Paperback) Online at Lulu. (Standard Copyright License) p.84, retrieved from: http:/www.lulu.com/ca/fr/shop/ kelvin-esiasa/highway-to-m-destiny/paperback/product-21965275.html

Giddings, M., Vodde, R. \& Cleveland, P. (2003). Examining Student-Field Instructor Problem in Practicum: Beyond Student Satisfaction Measures, The Clinical Supervisor, vol.22:2, pp.191-214.

Gelman, S.R., Pollack, D. \& Auerbach, C. (1996). Liability Issues in Social Work Education, Journal of Social Work Education, vol. 351:3, pp.351-61.

Gelman, C. R. (2004). Field Education in Social Work Anxiety Experienced by Foundation-Year MSW Students Entering Field Placement: Implications for Admissions, Curriculum, and Field Education. Journal of Social Work Education, vol.40, pp.39-40.

Garthwait, G. (2014). Social Work Practicum: A Guide and Workbook for Students, 6th edition. Pearson, London.

Hesse-Biber, S. \& Leavy, P. (2006). The Practice of Qualitative Research: Engaging Students in the Research, Thousand Oaks, CA: Sage. $2^{\text {nd }}$ Edition. 
Higher Education Commission Pakistan (2015). Curriculum of Social Work BS/MS, retrieved from: http://hec.gov.pk/english/services/universities/ RevisedCurricula/Documents/2014-15/Final\%20Curriculum\%20Social\% 20Work.pdf

IASSW \& IFSW (2004). Global Standards for the Education and Training of the Social Work Profession, Bern, Switzerland, Sage.

Kadushin, A. \& Harkness, D. (2002). Supervision in Social Work, 4th edition, Columbia University Press, New York.

Konrad, Alison M. Ritchie Jr., J. Edgar; Lieb, Pamela; Corrigall, Elizabeth. (2000). Sex Differences and Similarities in Job Attribute Preferences: A Meta-Analysis, Psychological Bulletin, vol.126:4, pp.593-641. http://dx.doi.org/10.1037/0033-2909.126.4.593

Lomax Robert \&Jones Karen. (2014). Surviving Your Social Work Placement, $2^{\text {nd }}$ Edition, Palgrave Macmillan.UK. p.2.

Mngomezulu, B.R. (2013). What does the Africanisation of a University Entail? Lessons from East Africa. Africa Journal of Politics, Economics and Society, vol.3:1\&2, pp.97-113.

Munson, C. E. (1993). Clinical Social Work Supervision, $2^{\text {nd }}$ edition, The Haworth Press Inc., New York.

National Association of Social Workers (2016). NASW Standards for Social Work Practice in Health Care Settings, p.39. https://www.socialworkers.org/ practice/standards/NASWHealthCareStandards.pdf

National Social Work Qualifications Board. (2006). Social Work Posts in Ireland: A Survey Conducted by the NSWQB, Dublin: NSWQB.

Parker, J. (2007). Developing Effective Practice Learning for Tomorrow's Social Workers, Social Work Education, vol.26:8, pp.763-779.

Papouli, E. (2014). Field Learning in Social Work Education: Implications for Educators and Instructors, Field Educator Simmons School of Social Work, vol.4.2, pp.1-15. http://www2.simmons.edu/ssw/fe/i/Papouli_Field_ Learning.pdf. 
Rompf, E. L., Royse, D. \& Dhooper, S. S. (1993). Anxiety preceding Field Work: What Students Worry about? Journal of Teaching in Social Work, vol.7, pp.81-95.

Royse, R., Dhooper, S. S. \& Rompf, E.L. (2003). Field Instruction: A Guide for Social Work Students, (4th ed.). Boston.

Shulman, L. (1993). Interactional Supervision, NASW Press, Washington, DC.

Shardlow, S. M. \& Doel, M. (1996). Practice Learning and Teaching. Basingstoke: Macmillan.

Singh, S. \& Srivastava, P. S. (2003). Social Work Education in India: Challenges and Opportunities in Lucknow, New Royal Book Co.

Tepper, B. J. (2000). Consequences of Abusive Supervision. Academy of Management Journal, vol.43, pp.178-190.

Dr. Sakina Riaz is an Assistant Professor in the Department of Social Work, University of Karachi. 